\title{
CDIO Approach in Developing Teacher Training Program to Meet Requirement of the Industrial Revolution 4.0 in Vietnam
}

\author{
https://doi.org/10.3991/ijet.v15i18.15517 \\ Nhi Thi Nguyen $(\bowtie)$ \\ Vinh University, Vinh city, Vietnam \\ hongnhi1076@gmail.com \\ Thanh Van Thai \\ Nghe An Department of Education and Training, Vietnam \\ Huong Thi Pham, Giang Chau Thi Nguyen \\ Vinh University- Vinh city, Vietnam
}

\begin{abstract}
In the context of the Industrial Revolution 4.0 and integration of the Vietnamese economy into the global economy, Vietnam's education and training has been increasingly developed and increasingly deeply integrated into the world. The development of teacher training programs is considered an urgent issue, a prerequisite to contribute positively to the development of education and training in the country. However, the first period of integration shows that teachers have many limitations in practical skills, soft skills, and foreign languages when working in a modern environment. These limitations are due to many factors; one of the basic factors is that the training programs at teacher training facilities are mainly focused on knowledge towards approaching content. Therefore, the development of training programs in general and teacher training programs in particular in the direction of developing necessary skills that society requires learners to have, in order to work and develop their qualities after graduation, to meet the integration needs in the context of the industrial revolution 4.0 is an important trend in the world and especially for Vietnam in the current period. CDIO stands for words: Conceive, Design, Implement and Operate. It is a solution to improve the quality of training to meet social requirements, on the basis of determining the outcome standards, developing programs and training plans; It is also the idea of universities, technical institutes of the United States and Sweden in the early 90 s of the last century with the intention of training students after graduation with full knowledge and skills such as: communication skills, personal skills ... and immediate access to the labor market, meeting the needs of the business. In this article, we focus on the solution to develop teacher training programs under the CDIO approach to meet the requirements of the Industrial Revolution 4.0 in higher education institutions in Vietnam.
\end{abstract}

Keywords - CDIO, Training program, teachers, development of training program, the Industrial Revolution 4.0. 


\section{$1 \quad$ Introduction}

The present world has been experiencing the most significant changes. The forth Industrial Revolution 4.0 or Industry 4.0 has been creating strong evolutions, influencing on every aspect of people's life in the 21th century [1][2]. This revolution will have significant influence on global economy and society in which education plays an important part[3]. It poses urgent issues for education. If we considered education, especially higher education, as a preparation for learners to confidently step to the world of work, universities are required to equip them with necessary skills, not just for their present but also for their future as well. To meet the human resource requirements for the new industry and make use of Information Technology, many universities worldwide have been innovating comprehensively [4][5]. Universities have been questioning how to innovate teaching methods, develop training curriculum, apply IT advances to upgrade the efficiency of teaching and learning and increase the popularity of teaching and learning. The Vietnam Ministry of Education and Training (MOET) encourage universities to carry out the fundamental and comprehensive reform requirements of the education sector in the spirit of the 12th National Party Congress's Resolution, approaching to a modern and internationally integrated education with the trend of innovation in teaching methods, testing and assessment, development of teaching staff and educational managers, individual branding to attract learners and most importantly, to a satisfaction of the increasing demands of the society. In the time when the education and training tailored to meet the requirements of the society and enterprises have become an essential factor to the socio-economic development, the approach to CDIO is an inevitable part towards advancement, in accordance with the trend and tendency of the world development, combining academic curriculum development with Higher education transfer and assessment, contributing to an improvement of the teaching and learning quality of universities in global innovation and integration that takes place worldwide [6][7].

With the goal of fundamental and comprehensive innovation in higher education towards strongly shifting the educational process from the main objective of equipping knowledge to comprehensive development of learners' qualities and competencies, the universities in general, teacher training institutions in particular need to implement innovations from training programs to teaching organizations. Accordingly, universities and teacher training institutions need to apply advanced approaches to develop training programs that meet the requirements of the Industrial Revolution 4.0. One of the innovations is the CDIO approach in developing training programs - an advanced training technology to meet social needs, to meet international quality standards. In this study, our research questions are as follows:

1. Is it possible to approach CDIO in developing teacher training programs to meet the requirements of high school teacher standards and the Industrial Revolution 4.0 ?

2. How is the process for development of teacher training programs based on a CDIO approach? 


\section{Methodology}

This research employed qualitative approach that means an approach in which data processing does not involve mathematical and statistical calculations but emphasize interpretative studies [8]. This research involved literature review type. Literature review is an activity relating to the method of collecting references, reading, recording it, and collecting research materials from various literatures without requiring field research. The technique of collecting data in this research used document analysis. Documents analyzed in this research consist of research journals, literature journals, and Seminar reports. On the other hand, researcher collected data by reading, organizing topics, and recording important information on references. The steps in this research included:

- Exploring general ideas on research topics

- Looking for literature that relevant with research topics

- Empahsizing the focus of research topics and organizing relevant literatures

- Reviewing literatures through content analysis

- Synthesize and gain a new perspective on a topic

- Make a new contribution on a topic

Meanwhile, data analysis employed analysis [9]. Content analysis is used to analyze the meanings contained in literature review then each analysis results is coded and interpreted. Then, data interpretation was done descriptively to draw an overview and explain the information that has been analyzed.

\section{The Industrial Revolution 4.0}

The term "the Industrial Revolution 4.0" or "the fourth Industrial Revolution" was first mentioned in 2011 at the Hannover fair to introduce industrial programs 4.0, to promote the industry of automation and traditional mechanics of Germany[10]. The Industry 4.0 Expert Group presented a series of recommendations on the realization of Industry 4.0 for the German federal government[11]. Members of this expert group have been recognized as the founders and are the driving force behind the Industrie 4.0[12]. According to Gartner, the Industrial Revolution 4.0 stems from the concept of "Industrie 4.0" in a report submitted to the German government in 2013. "Industrie 4.0 " connects embedded systems and smart manufacturing facilities to create digital convergence between industry, business, internal functions and processes[1].

The first Industrial Revolution began in England from the second half of the $18^{\text {th }}$ century. There has been a unified view of the three industrial revolutions that have occurred, each of which is characterized by a change in the nature of the manufacturing process and this change is caused by a breakthrough progress of science and technology. The first Industrial Revolution (1.0) used water and steam energy to mechanize production. The second Industrial Revolution (2.0) took place thanks to the application of electricity to conduct mass production. The third Industrial Revolution (3.0) used electronics and information technology to automate 
production processes. Currently, the fourth Industrial Revolution (4.0) is arising from the third revolution, which combines technologies together, blurring the boundaries between the physical world and the digital world (the virtual world) and the biological world (the world of life)[13].

According to Mr. Klaus Schwab, the breakthrough speed of the Industrial Revolution 4.0 has no historical precedent. In comparison with the previous three industrial revolutions, Industry 4.0 is progressing exponentially rather than linear speed or multiplier function. Moreover, due to the interdisciplinary nature and with information and communication technology as the foundation, it is currently disrupting most structures of industries in every country. It foreshadows the transformation of both the breadth and depth of the entire production, business and management system on a global scale.

Currently, the Industrial Revolution 4.0 is taking place in developed countries such as the US, Europe and some advanced Asian countries (Korea, Japan)[14]. Besides the new opportunities, the Industrial Revolution 4.0 also presents humankind with many challenges to face. Table 1 presents some of the outstanding opportunities and challenges associated with the Industrial Revolution 4.0 for society, organizations and the economy.

Table 1. Opportunities and challenges associated with the Industrial Revolution 4.0

\begin{tabular}{|c|c|}
\hline Opportunities & Challenges \\
\hline $\begin{array}{l}\text { Many new professions, start-up opportunities and } \\
\text { new jobs appear }\end{array}$ & $\begin{array}{l}\text { States of instability, inequality, imbalance in labor } \\
\text { market. }\end{array}$ \\
\hline $\begin{array}{l}\text { An increase in labor and production productivity. } \\
\text { Economic growth is based on a new business model. }\end{array}$ & $\begin{array}{l}\text { Issue of training a quality new human resource in } \\
\text { terms of converging skills and appropriate } \\
\text { competence. }\end{array}$ \\
\hline $\begin{array}{l}\text { High personalization, social connection in new } \\
\text { ways. }\end{array}$ & $\begin{array}{l}\text { Change in the way of production, distribution and } \\
\text { consumption. }\end{array}$ \\
\hline $\begin{array}{l}\text { Promote the initiative and creative spirit of } \\
\text { individuals and businesses }\end{array}$ & $\begin{array}{l}\text { Developing countries will lose the advantage of cheap } \\
\text { labor. }\end{array}$ \\
\hline
\end{tabular}

For the above opportunities and challenges, the question for researchers is how governments, businesses and entrepreneurs will have to deal with in order to succeed and gain advantage of sustainable competitiveness in the context of the Industrial Revolution 4.0 is imminent. The next question is what the role of universities will be for other actors of the economy. Certainly, universities also face similar opportunities and challenges. In particular, teacher training facilities also need a lot of changes during the training process.

Along with the rapid change of technology, during the Industrial Revolution 4.0, education is required to provide learners with basic skills and knowledge, creative thinking and adaptability to job challenges and requirements that change constantly to avoid the risk of being left behind and eliminated. There are many new requirements for education and training that traditional methods of education will certainly not be able to meet. In this context, the quality of higher education is a top concern of universities in Vietnam. For teacher training facilities, it is necessary to improve the capacity of training and fostering teachers and education administrators. The first is to 
develop the training programs of the sectors towards a capacity approach to meet the requirements of the Industrial Revolution 4.0. In which CDIO is an approach applied by many universities in developing training programs.

\section{The CDIO approach}

The CDIO approach is one of the most systematic and comprehensive approaches to design, implementation and evaluation of the quality of engineering programmes (http://cdio.org). The CDIO approach was initially developed by Massachusetts Institute of Technology (USA) and three Swedish universities (Chalmers University of Technology, KTH Royal Institute of Technology and Linköping University). The approach aims to educate and train engineers 'of a new generation' in the context of complex engineering activity (CDIO - Conceive, Design, Implement, Operate)[15].

The CDIO approach is essentially a social needs-based training approach that contributes to the shortening of the gap between the school and the human resource user, through investigations and surveys to build objectives and content of training[16]. The CDIO approach aims to implement competence-based higher education including "hard skills" and "soft skills" for learners, giving learners the potential to develop and quickly adapt to the changeable working environment[17]. The CDIO approach is a developmental approach that gives the program development science a new step of development, associating program development with the method of transferring and evaluating the effectiveness of higher education, contributing to raising the quality of higher education to a new level[6]. CDIO is not only an approach to designing and developing training programs in a scientific and modern way, with the perspective of teaching theory, CDIO also suggests a "teaching technology" process[18].

The process of adapting and implementing the CDIO approach is closely aligned with the phases of the product, process, and system lifecycle, as illustrated in Fig.1. The approach uses the techniques of product, process, and system development to structure an educational program based on the premise that the proper context for engineering education is the product, process, and system lifecycle[19]. The Conceive phase analyzes the needs of a graduating engineer, sets clear and consistent learning outcomes, and works out a concept for engineering education that addresses requirements. This concept for engineering education is consistent with university and national goals and standards and reflects scientifc and technical advances. The outcomes of the Conceive phase are unique for each program but are guided by the CDIO Syllabus and the CDIO Standards. The Design phase includes benchmarking the existing curriculum and using opensource tools that help in curriculum development, course development, teaching and learning methods, assessment methods, and student workspaces. In the Implement phase, new educational tools and resources are tested in engineering programs at collaborating universities. This collaboration enables programs to compare results, evaluate, iterate, and improve processes and materials, and adapt the approach to engineering programs in a variety of educational environments. It is in this phase that human and physical resources are 
developed. Finally, the Operate phase occurs when the educational reform initiatives move beyond prototype and test stages to a steady-state phase where major program changes have been implemented. Evaluation and continuous improvement of the program and of the CDIO approach continue in this phase and are supported by assessment and evaluation.

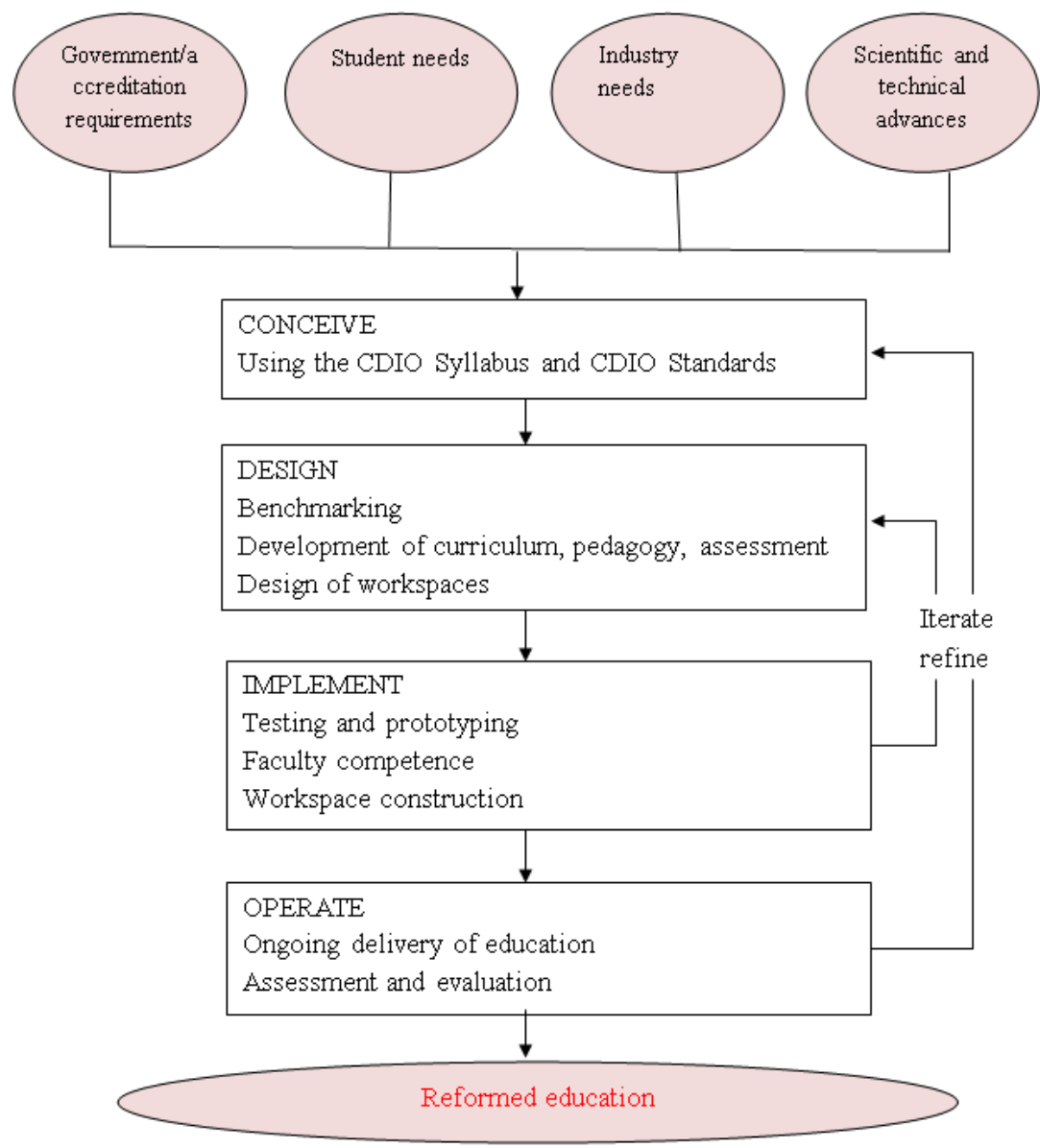

Fig. 1. Design and development of a CDIO approach [18]

Developing a training program in the direction of CDIO approach is essentially redesigning the training program according to a certain process and must bases on the outcome standards to design, select inputs, build a framework of program and training plan in detail completely in most effective manner. The development of the outcome standards according to the model of CDIO is based on a thorough survey, study of current market requirements and future development trends. The outcome standards are shown in 4 blocks of knowledge, key skills include: 
1) Specialized knowledge

2) Personal skills, attitude and career

3) Communication skills and behavior

4) Competence in forming ideas, design ideas, implement and operate in social and business contexts

To address these issues, the CDIO model addresses 12 standards that fully reflect process of training and quality management:

1) Background

2) Standard output

3) Integrated training program

4) Introduction to technology

5) Design experiences - implementation

6) CDIO learning space

7) Integrated learning experiences

8) Active learning

9) Improvement of competence on CDIO skills for lecturers

10) Improvement of competence on teaching skills for lecturers

11) Evaluation of students' learning

12) Evaluation of the CDIO program [19].

The description of 12 CDIO Standards is shown in column 2, Table 2. Thus, CDIO Standards enable expedient design of engineering programmes focusing on the answers to the key questions of education: 'What skills should engineering programme graduates have?,' 'How should the graduates acquire these skills?,' 'How should engineering programme graduates demonstrate their skills to the best advantage?,' 'How should teachers assess them?,' 'How should engineering programmes be taught?,' 'How should teachers help the engineering students develop their skills and abilities before they graduate?,' and 'How should teachers be helped to acquire these skills/competencies in order to effectively teach them to their students?' The answers to these questions imply meeting three major challenges: planning, progress and evaluation of engineering programme implementation.

Table 2. Twelve CDIO Standards and learning outcomes of the programme.

\begin{tabular}{|l|l|l|}
\hline CDIO Standard & \multicolumn{1}{|c|}{ Description of the standard } & $\begin{array}{l}\text { Learning outcome of the CDIO approach } \\
\text { teacher training programme }\end{array}$ \\
\hline $\begin{array}{l}\text { CDIO Standard 1 } \\
\text { Background }\end{array}$ & $\begin{array}{l}\text { Adoption of the principle that product, } \\
\text { process and system lifecycle } \\
\text { development and deployment - } \\
\text { Conceiving, Designing, Implementing } \\
\text { and Operating - are the context for } \\
\text { technical education }\end{array}$ & $\begin{array}{l}\text { Ability to apply the CDIO philosophy which } \\
\text { is based on the principle of development and } \\
\text { implementation of products, processes and } \\
\text { systems with their whole lifecycles in mind } \\
\text { and using the CDIO context to determine the } \\
\text { content of teacher education. }\end{array}$ \\
\hline $\begin{array}{l}\text { CDIO Standard 2 } \\
\text { Learning outcomes }\end{array}$ & $\begin{array}{l}\text { Specific, detailed learning outcomes for } \\
\text { personal and interpersonal skills, and } \\
\text { product, process, and system building } \\
\text { skills, as well as disciplinary knowledge } \\
\text { consistent with programme goals and }\end{array}$ & $\begin{array}{l}\text { Ability to plan comprehensive results of } \\
\text { teacher training programme implementation } \\
\text { aiming at the development of professional, } \\
\text { personal and interpersonal competences of } \\
\text { graduates, of the skills required to create }\end{array}$ \\
\hline
\end{tabular}




\begin{tabular}{|c|c|c|}
\hline & validated by programme stakeholders & $\begin{array}{l}\text { products, processes and systems, as well as } \\
\text { of their disciplinary knowledge }\end{array}$ \\
\hline $\begin{array}{l}\text { CDIO Standard } 3 \\
\text { Technical training }\end{array}$ & $\begin{array}{l}\text { A curriculum designed with mutually } \\
\text { supporting disciplinary courses, with an } \\
\text { explicit plan to integrate personal and } \\
\text { interpersonal skills, and product, process, } \\
\text { and system building skills }\end{array}$ & $\begin{array}{l}\text { Ability to design an integrated curriculum } \\
\text { that contains interrelated and associated } \\
\text { disciplines, including modules that provide } \\
\text { formation of personal and interpersonal } \\
\text { competences of graduates and the skills } \\
\text { aimed at creation of products, processes and } \\
\text { systems }\end{array}$ \\
\hline $\begin{array}{l}\text { CDIO Standard } 4 \\
\text { Introduction to } \\
\text { technology }\end{array}$ & $\begin{array}{l}\text { An introductory course that provides the } \\
\text { framework for engineering practice in } \\
\text { product, process and system building, } \\
\text { and introduces essential personal and } \\
\text { interpersonal skills }\end{array}$ & $\begin{array}{l}\text { Ability to develop and implement an } \\
\text { integrated curriculum module 'Introduction } \\
\text { to teacher training' }\end{array}$ \\
\hline $\begin{array}{l}\text { CDIO Standard } 5 \\
\text { Design-implement } \\
\text { experiences }\end{array}$ & $\begin{array}{l}\text { A curriculum that includes two or more } \\
\text { design-implement experiences, including } \\
\text { one at a basic level and one at an } \\
\text { advanced level }\end{array}$ & $\begin{array}{l}\text { Ability to organise design-implement student } \\
\text { learning activities through implementation of } \\
\text { projects at both basic and advanced levels } \\
\text { within the curriculum }\end{array}$ \\
\hline $\begin{array}{l}\text { CDIO Standard } 6 \\
\text { learning space }\end{array}$ & \begin{tabular}{|l|} 
Technical workspaces and laboratories \\
support and encourage hands-on learning \\
in creating products, processes and \\
systems, specialised knowledge, social \\
studies.
\end{tabular} & $\begin{array}{l}\text { Ability to create a workspace for engineering } \\
\text { activity and relevant laboratory facilities that } \\
\text { contribute to the development of practical } \\
\text { methods required by students to create } \\
\text { efficient products, processes and systems. }\end{array}$ \\
\hline $\begin{array}{l}\text { CDIO Standard } 7 \\
\text { Integrated learning } \\
\text { experiences. }\end{array}$ & $\begin{array}{l}\text { Integrated learning experiences that lead } \\
\text { to the acquisition of disciplinary } \\
\text { knowledge, as well as personal and } \\
\text { interpersonal skills, and product, process, } \\
\text { and system building skills }\end{array}$ & $\begin{array}{l}\text { Ability to organise integrated education of } \\
\text { students, promoting their disciplinary } \\
\text { knowledge, personal and interpersonal } \\
\text { competences, as well as the skills to develop } \\
\text { products, processes and systems. }\end{array}$ \\
\hline $\begin{array}{l}\text { CDIO Standard } 8 \\
\text { Active learning }\end{array}$ & $\begin{array}{l}\text { Teaching } \\
\text { experienti }\end{array}$ & $\begin{array}{l}\text { Ability to apply active learning methods } \\
\text { (team work, case studies, business games and } \\
\text { role-plays, problem-based and context-based } \\
\text { learning, experience-based learning), } \\
\text { offering enhanced quality development of } \\
\text { teacher training programmes }\end{array}$ \\
\hline $\begin{array}{l}\text { CDIO Standard } 9 \\
\text { Capacity of } \\
\text { lecturers on CDIO } \\
\text { skills }\end{array}$ & $\begin{array}{l}\text { Actions are taken that enhance faculty } \\
\text { competence in personal and interpersonal } \\
\text { skills, product, process and system- } \\
\text { building skills. }\end{array}$ & $\begin{array}{l}\text { Ability to organise events enabling faculty } \\
\text { staff to develop personal and interpersonal } \\
\text { competences, as well as skills to create } \\
\text { products, processes and systems resulting } \\
\text { from their engineering activity }\end{array}$ \\
\hline $\begin{array}{l}\text { CDIO Standard } 10 \\
\text { Enhancing } \\
\text { lecturers' } \\
\text { competence in } \\
\text { teaching skills }\end{array}$ & $\begin{array}{l}\text { Actions that enhance faculty competence } \\
\text { in providing integrated learning } \\
\text { experiences, in using active experiential } \\
\text { learning methods and in assessing } \\
\text { student learning }\end{array}$ & $\begin{array}{l}\text { Ability to organise activities aimed at } \\
\text { enhancing teaching competence including } \\
\text { application of active teaching methods and } \\
\text { assessment tools for complex learning } \\
\text { outcomes }\end{array}$ \\
\hline $\begin{array}{l}\text { CDIO Standard } 11 \\
\text { Assessing } \\
\text { students' learning }\end{array}$ & $\begin{array}{l}\text { Students' learning on communication } \\
\text { skills, product creation processes and } \\
\text { systems and specialised knowledge is } \\
\text { evaluated }\end{array}$ & $\begin{array}{l}\text { Ability to assess students' acquisition of } \\
\text { disciplinary knowledge, personal and } \\
\text { interpersonal competences, skills aimed at } \\
\text { creating novel engineering products, efficient } \\
\text { processes and systems }\end{array}$ \\
\hline $\begin{array}{l}\text { CDIO Standard } 12 \\
\text { Evaluation of } \\
\text { CDIO program }\end{array}$ & $\begin{array}{l}\text { A system that evaluates programmes } \\
\text { against these } 12 \text { standards, and provides } \\
\text { feedback to students, faculty and other } \\
\text { stakeholders for the purposes of } \\
\text { continuous improvement }\end{array}$ & $\begin{array}{l}\text { Ability to assess the programme compliance } \\
\text { with the requirements of all CDIO Standards } \\
\text { for teacher training programmes and provide } \\
\text { feedback to students, teachers, employers } \\
\text { and other interested parties with their } \\
\text { continuous improvement in view. }\end{array}$ \\
\hline
\end{tabular}


Figure 2 describes Implementing the CDIO approach in detail. From the experiments that have been applied successfully in technical education both in the world and in Vietnam, the CDIO model is also applicable to programs outside the technical field for continuous and comprehensive improvement [18].

For example, it is possible to access CDIO in training social sciences, in teacher training.

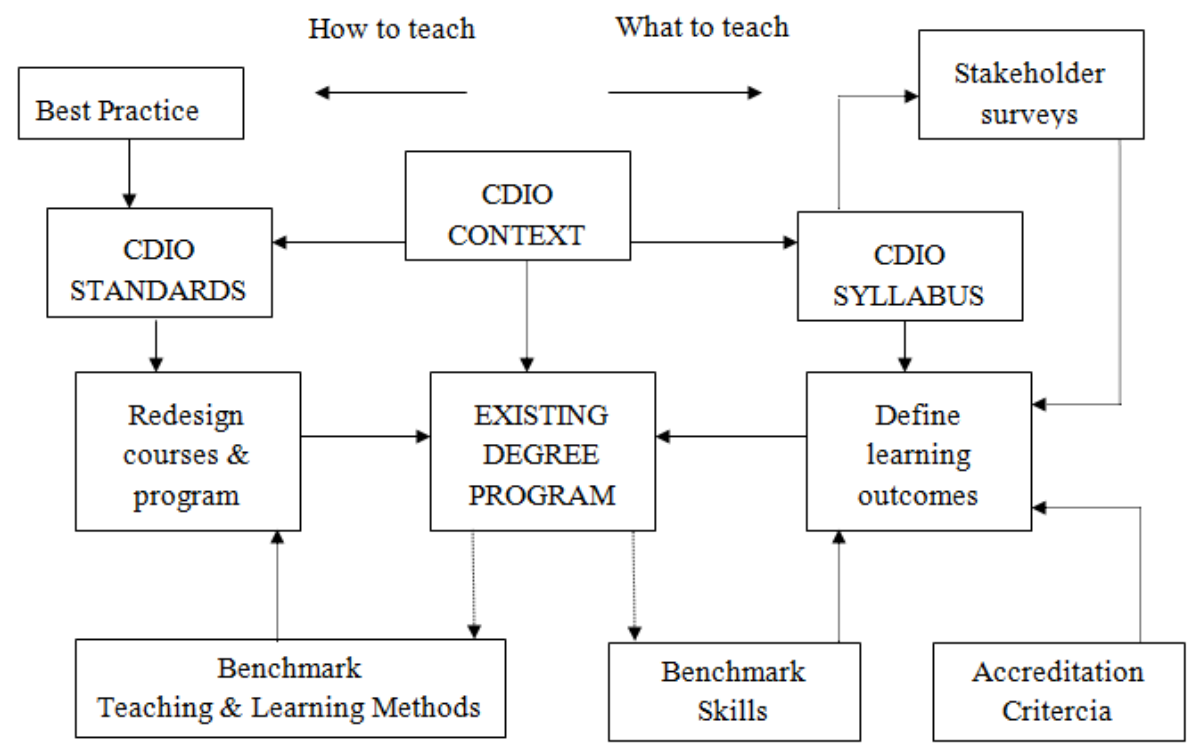

Fig. 2. Implementing the CDIO approach

\section{$5 \quad$ Results and Discussions}

For higher education institutions with teacher training in Vietnam in particular, countries in general, the implementation of initiatives to improve training quality to meet the social needs and requirements of the Industrial Revolution 4.0 is indispensable[20]. Particularly, attention should be paid to the development of training programs for specific sectors. There are many different approaches to developing higher education programs[3]. However, when we consider the nature of the CDIO approach to developing higher education programs, we see that it is the process of setting up the target system/outcome standard for training products. Các mục tiêu/chuẩn đầu ra này gồm Disciplinary knowledge; Personal skills; Interpersonal skills; CDIO in enterprise, societal, and environmental context. This is described in detail in Table 3[21]. 


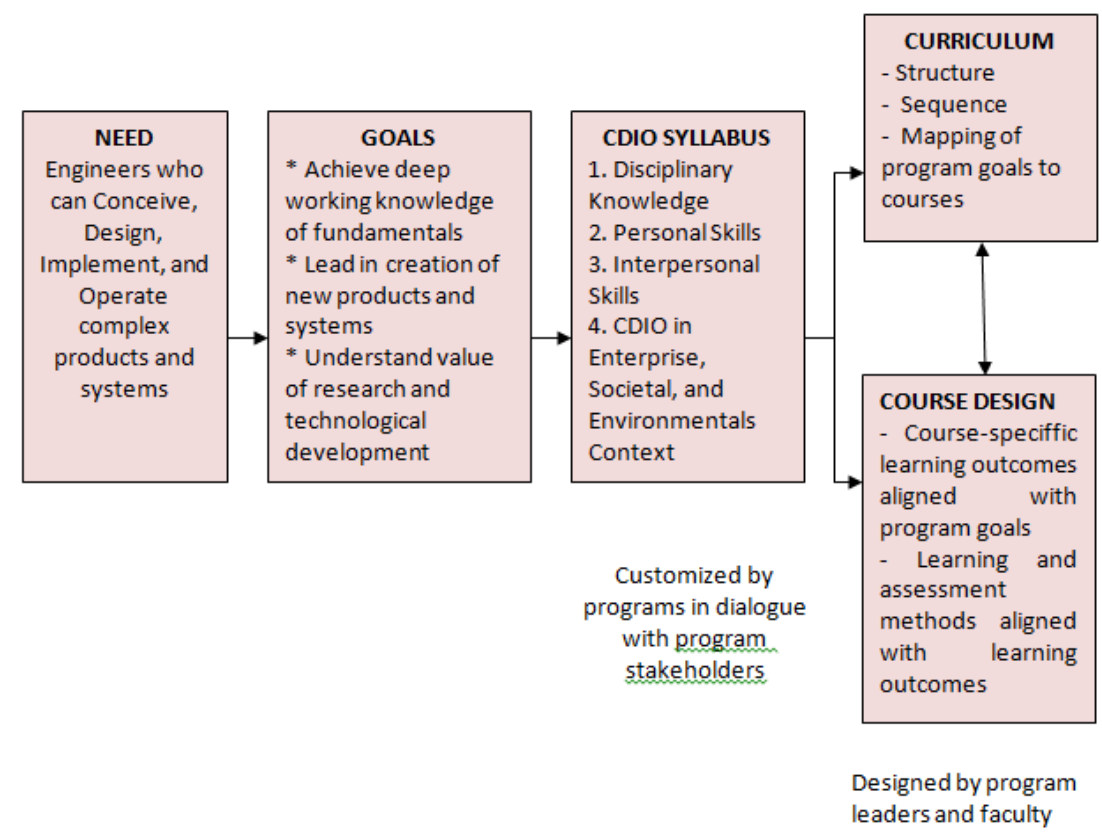

Fig. 3. Development and integration of the CDIO Syllabus

Besides, when considering the professional standard of high school teacher in Vietnam, we see that it is also the minimum outcome standard/target system for high school teacher training products. Specifically, professional standards of teachers of general education institutions are issued in accordance with the Circular No. 20/2018/TT-BGD \&ĐT by the Ministry of Education and Training of Vietnam on August 22, 2018 which can be summarized as follows:

Table 3. Professional standards of teachers in Vietnam and collated with the pillars in CDIO

\begin{tabular}{|c|c|c|}
\hline Standard & Criteria & Outcome standards according to CDIO \\
\hline $\begin{array}{l}\text { Standard 1. Teacher's } \\
\text { qualities }\end{array}$ & $\begin{array}{l}\text { 1. Criteria 1. Ethics of teachers } \\
\text { 2. Criteria 2. Teacher's style }\end{array}$ & Skills, personal and professional qualities \\
\hline $\begin{array}{l}\text { Standard } 2 . \\
\text { Development of } \\
\text { profession and } \\
\text { operation }\end{array}$ & $\begin{array}{l}\text { 1. Criteria 3. Development of own } \\
\text { expertise } \\
\text { 2. Criteria 4. Develop teaching and } \\
\text { education plans in the direction of } \\
\text { developing students' qualities and } \\
\text { competencies } \\
\text { 3. Criteria 5. Use teaching and } \\
\text { educational methods towards } \\
\text { developing students' qualities and } \\
\text { competencies } \\
\text { 4. Criteria } 6 \text {. Test and evaluate towards } \\
\text { developing students' qualities and } \\
\text { competencies } \\
\text { 5. Criteria 7. Counsel and support } \\
\text { student }\end{array}$ & $\begin{array}{l}\text { Knowledge and arguments of sectors; } \\
\text { CDIO Competence (Professional practice } \\
\text { competence) }\end{array}$ \\
\hline
\end{tabular}




\begin{tabular}{|c|c|c|}
\hline $\begin{array}{l}\text { Standard } 3 \text {. } \\
\text { Construction of an } \\
\text { educational } \\
\text { environment }\end{array}$ & $\begin{array}{l}\text { 1. Criteria } 8 \text {. Construction of the } \\
\text { school culture } \\
\text { 2. Criteria } 9 \text {. Implementation of } \\
\text { democratic rights in schools } \\
\text { 3. Criteria } 10 \text {. Implementation and } \\
\text { construction of safe schools and } \\
\text { prevention of school violence }\end{array}$ & $\begin{array}{l}\text { Communication skills CDIO competence } \\
\text { (Competence of professional practice) }\end{array}$ \\
\hline $\begin{array}{l}\text { Standard } 4 \text {. Develop } \\
\text { relationships between } \\
\text { school, family and } \\
\text { society }\end{array}$ & $\begin{array}{l}\text { 1. Criteria 11. Build collaborative } \\
\text { relationships with parents or guardians } \\
\text { of students and stakeholders } \\
\text { 2. Criteria } 12 \text {. Collaborate with the } \\
\text { school, family, and society to perform } \\
\text { teaching activities for students } \\
\text { 3. Criteria 13. Collaborate with the } \\
\text { school, family, and society to carry out } \\
\text { ethical education and lifestyle for } \\
\text { students }\end{array}$ & $\begin{array}{l}\text { Communication skills CDIO competence } \\
\text { (Competence of professional practice) }\end{array}$ \\
\hline \begin{tabular}{|l|} 
Standard 5. Use of \\
foreign languages or \\
ethnic languages, \\
application of \\
information technology, \\
exploitation and use of \\
technological \\
equipment in teaching \\
and education
\end{tabular} & $\begin{array}{l}\text { 1. Criteria 14. Use foreign languages or } \\
\text { ethnic languages } \\
\text { 2. Criteria } 15 \text {. Application of } \\
\text { information technology, exploitation } \\
\text { and use of technological equipment in } \\
\text { teaching and education. }\end{array}$ & $\begin{array}{l}\text { Specialized knowledge and arguments; } \\
\text { CDIO competence (Competence of } \\
\text { professional practice) }\end{array}$ \\
\hline
\end{tabular}

On the other hand, we can present 4 professional competencies of a bachelor in general and general education teachers in particular including $\mathrm{C}, \mathrm{D}, \mathrm{I}$ and $\mathrm{O}$ through Table 4 below:

Table 4. Four professional competencies of high school teachers

\begin{tabular}{|l|l|l|l|}
\hline \multicolumn{1}{|c|}{ C } & \multicolumn{1}{|c|}{ D } & \multicolumn{1}{c|}{ I } \\
\hline - Idea & -Design & - Enforce & - Operate \\
- Discover & - Build & - Perform & - Control \\
- Survey & -Make plan & - Deploy & - Manage \\
- Offer & -Propose solution & - Operate & - Evaluate \\
- Raise the problem & $-\ldots \ldots \ldots .$. & $-\ldots \ldots \ldots .$. & $-\ldots \ldots \ldots$ \\
\hline
\end{tabular}

So, we see that:

1) CDIO and teacher standards in Vietnam are built according to a competency approach

2) The career activities (profession and operation of Vietnamese general education teachers are contained in 4 outcome standards by CDIO.

3) Standards and criteria according to the professional standards of general education teachers basically follow the CDIO logic.

From that, it can be said that the application of CDIO approach in developing teacher training programs in higher education institutions in Vietnam is completely reasonable and scientific. This model can be described in Figure 4 . 


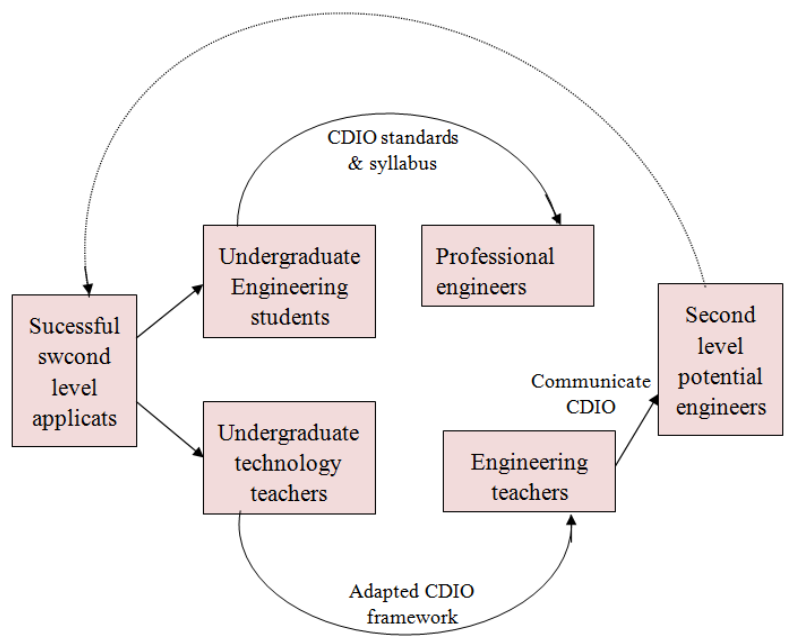

Fig. 4. Adapting CDIO for teacher training [17]

On that basis, we have applied CDIO in developing the pedagogical bachelor training program in Physics at a university of education in Vietnam following the 6step process:

Step 1: Collate the current training programs with the new outcome standards. Outcome standards are the basis for the design of new training programs.

Step 2: Design training program frame. Restructure the training program to new outcome standards, and new ideas. In this case, it is designed according to the principle of integrated training program. Use the integrated structure which allows to make full use of the time fund and create conditions for students to develop in terms of both professional knowledge and necessary skills and attitudes, as required by Standard 7-CDIO. Thus, the training program is organized according to the subjects and is interwoven with big exercises and projects for students to practice their skills and attitudes. Content of subjects should also be considered so that there are links and support between the subjects. The result of this step is the new training program frame.

Step 3: Design teaching sequence of outcome standard topics on skills and attitudes. The sequence of teaching the outcome standard topics through the properly established subjects, the learning will develop in a cycle where each knowledge, skill and attitude will be built and strengthened on the basis of the previous knowledge, skills and attitudes.

Step 4: Allocate the sequence of teaching topics into modules. This process shows how skills and attitudes are intertwined in the subjects. The result of the teaching sequence allocation is a matrix of modules, in which one axis lists the modules, the second lists the outcome standard topics. Lecturers of the modules need to be deeply involved in the process of designing teaching sequences, and allocation of sequences into modules, to comment on the feasibility of integrating certain skills and attitudes into in the professional content they are in charge of teaching. By participating in the 
design or completion of the training program, through stages of revision and iteration, lecturers have the right to own it.

Step 5: Design the outline of the modules. After agreeing on the allocation of the teaching sequence of the outcome standard topics into the modules, each lecturer can design the module outline according to the outcome standards that have been allocated to her/his module. The design process can be repeated many times. In the CDIO-based training program, each module, at a different angle, contributes to achieving the overall outcome standards. Therefore, each lecturer must abide by the program's standards and make commitments on transmitting the outcome standard of the module that he/she is in charge of.

Step 6: Develop survey form and collect comments on program frame, detailed content of the detailed outline of subjects by CDIO. After defining the main contents of the Detailed Outline under CDIO, the departments conduct collection of comments on the detailed outline under the CDIO. As follows: Making survey form of Detailed outline under CDIO; Conduct survey, get information: the objects of the survey here are lecturers, heads of subjects of Pedagogical Universities, educational experts; organize and collect votes. Each object related to the evaluation shows comments on the Detailed Outline, the subjects, knowledge, skills that need to be removed and supplemented, etc. Analyze, synthesize the survey results, make reports of the results collected during the survey; The scientific councils of departments hold meetings to adjust and finalize the detailed outline. The Department shall submit on the School Science Council for approval and issuance.

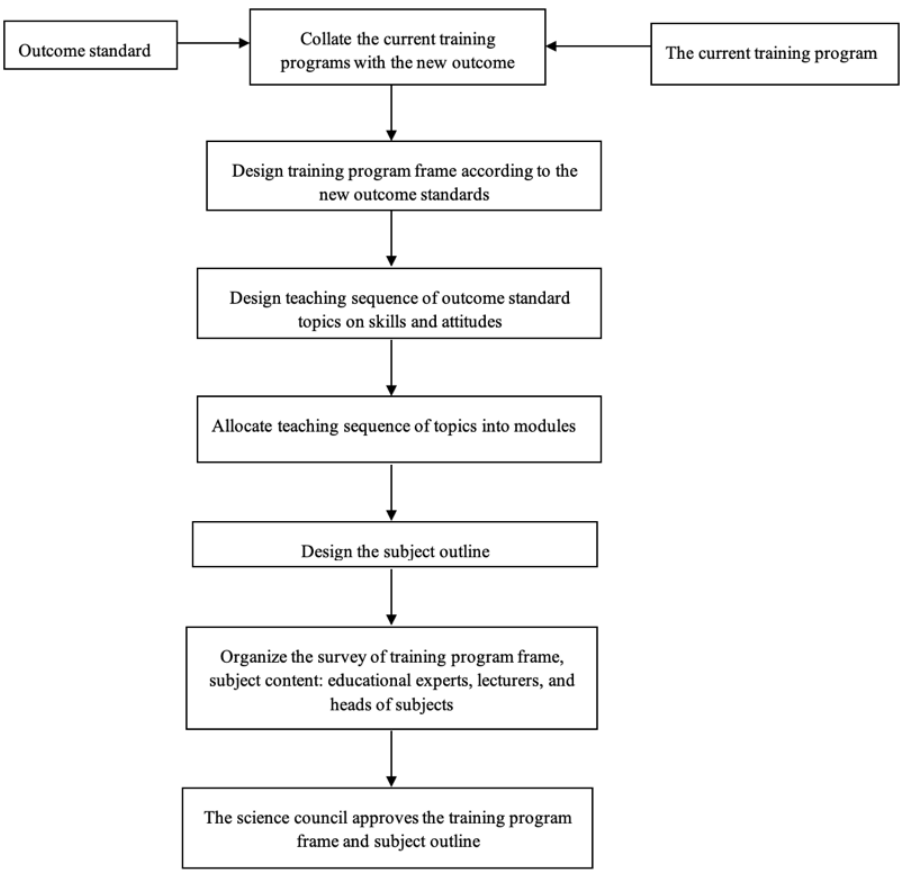

Fig. 5. Diagram of training program design process based on CDIO approach 


\section{Conclusion}

Training programs play a very important role in ensuring the quality of education. In order to develop a quality training program, it is necessary to derive from a competence approach that incorporates the needs of employers and society. Teacher training programs need to be regularly updated, in order to meet the increasing demands of society. When developing the training program, it must be paid attention to ensure flexibility. Flexibility is shown in that the program manager and operator as well as the instructor have the right to proactively propose adjusting the program within a certain scope to suit specific circumstances to achieve the set goals. On the other hand, flexibility also allows learners to choose subjects suitable to their career orientation, competence and interests. CDIO approach-based training is a model that links the training facilities with the requirements of the employer, thereby closing the gap between the school's training and the requirements of the employer; help students develop comprehensively with "hard skills" and "soft skills" to quickly adapt to the changable work environment; help training programs be developed and designed according to a standard procedure; the training process is interconnected and closely linked with science. For a long time, CDIO approach in developing and developing training programs has been applied to technical universities. However, with the analysis results in this article, we can apply the CDIO approach method in training in general, developing teacher training programs in particular in higher education facilities. In Vietnam, this contributes to helping graduates to meet the requirements of general education teacher standards, to meet the requirements of educational facilities and international integration in the context of the Industrial Revolution 4.0.

\section{$7 \quad$ Funding}

This work received no external funding.

\section{Reference}

[1] H. Karre, M. Hammer, M. Kleindienst, and C. Ramsauer, "Transition towards an Industry 4.0 State of the LeanLab at Graz University of Technology," Procedia Manuf., vol. 9, pp. 206-213, 2017. https://doi.org/10.1016/j.promfg.2017.04.006

[2] B. Yusuf, L. M. Walters, and S. N. Sailin, "Restructuring Educational Institutions for Growth in the Fourth Industrial Revolution (4IR): A Systematic Review," Int. J. Emerg. Technol. Learn., vol. 15, no. 03, p. 93, 2020. https://doi.org/10.3991/ijet.v15i03.11849

[3] L. Krasnova and V. Shurygin, "Blended learning of physics in the context of the professional development of teachers," Int. J. Emerg. Technol. Learn., vol. 14, no. 23, pp. 17-32, 2019. https://doi.org/10.3991/ijet.v14i23.11084

[4] E. G. Matviyevskaya, O. G. Tavstukha, O. V. Galustyan, P. A. Ignatov, and D. V. Miroshnikova, "Formation of information and communication competence of future teachers,” Int. J. Emerg. Technol. Learn., vol. 14, no. 19, pp. 65-76, 2019. https://doi.org/ $\underline{10.3991 / \text { ijet.v14i19.10990 }}$ 
[5] S. Davut Göker, “)! 1 Studies in Educational Research and Development,” vol. 1, no. 1, p. $1,2017$.

[6] Y. SHIMIZU, S. THOLLAR, Y. ANADA, and N. HAYATA, "The Application of CDIO Standards to Clinical Engineering Education," 2018.

[7] R. F. Mustapa, A. F. Z. Abidin, A. A. N. M. Amin, A. H. M. Nordin, and M. N. Hidayat, "Engineering is fun: Embedded CDIO elements in electrical and electronic engineering final year project," Proc. 2017 IEEE 9th Int. Conf. Eng. Educ. IEEE ICEED 2017, vol. 2018-Janua, pp. 1-6, 2017. https://doi.org/10.1109/iceed.2017.8251154

[8] and R. W. A.J. Onwuegbuzie, "A framework for using qualitative comparative analysis for the review of the literature," Qual. Rep., vol. 02, no. 2, pp. 359-372, 2017.

[9] A. J. O. and R. K. Frels, Seven steps to a comprehensive literature review: A multimodal and cultural approach. London, UK: Sage, 2016.

[10] Y. Liao, F. Deschamps, E. de F. R. Loures, and L. F. P. Ramos, "Past, present and future of Industry 4.0 - a systematic literature review and research agenda proposal,” Int. J. Prod. Res., vol. 55, no. 12, pp. 3609-3629, 2017. https://doi.org/10.1080/00207543.2017.13085 $\underline{76}$

[11] A. A. Galushkin, A. G. Nazarov, E. N. Sabyna, and T. V. Skryl, "The institutional model of formation and development of industry 4.0 in the conditions of knowledge economy's formation,” Stud. Syst. Decis. Control, vol. 169, pp. 219-226, 2019. https://doi.org/10.10 07/978-3-319-94310-7 22

[12] M. Gootting et al., "Methodology and case study for investigating curricula of study programs in regard to teaching industry 4.0," Proc. - 2017 IEEE 15th Int. Conf. Ind. Informatics, INDIN 2017, pp. 533-538, 2017. https://doi.org/10.1109/indin.2017.8104828

[13] A. Benesova, M. Hirman, F. Steiner, and J. Tupa, "Analysis of Education Requirements for Electronics Manufacturing within Concept Industry 4.0," Proc. Int. Spring Semin. Electron. Technol., vol. 2018-May, pp. 2-6, 2018. https://doi.org/10.1109/isse.2018.84436 $\underline{81}$

[14] A. Hariharasudan and S. Kot, "A scoping review on Digital English and Education 4.0 for Industry 4.0," Soc. Sci., vol. 7, no. 11, 2018.

[15] J. Bankel, K. F. Berggren, K. Blom, E. F. Crawley, I. Wiklund, and S. Östlund, "The CDIO syllabus: a comparative study of expected student proficiency,” Eur. J. Eng. Educ., vol. 28, no. 3, pp. 297-315, 2003. https://doi.org/10.1080/0304379031000098274

[16] A. Chuchalin, "Evolution of the CDIO approach: BEng, MSc, and PhD level," Eur. J. Eng. Educ., vol. 45, no. 1, pp. 103-112, 2020. https://doi.org/10.1080/03043797.2017.1422694

[17] R. Dunbar, N. Seery, and S. Gordon, "Implementing CDIO principles in an undergraduate teacher education program," CDIO Linkoping, no. June, 2006.

[18] C. R. Brito, M. M. Ciampi, R. M. Vasconcelos, L. A. Amaral, H. D. Santos, and V. A. Barros, Rethinking engineering education, vol. 2017-Octob. 2017.

[19] G. Gibbs et al., "The CDIO Syllabus A Statement of Goals for Undergraduate Engineering Education,” Eurasia J. Math. Sci. Technol. Educ., vol. 28, no. 1, pp. 118-127, 2001.

[20] A. Rajak, A. K. Shrivastava, and A. K. Tripathi, "An approach to evaluate program outcomes and program educational objectives through direct and indirect assessment tools,” Int. J. Emerg. Technol. Learn., vol. 14, no. 23, pp. 85-97, 2019. https://doi.org/10. 3991/ijet.v14i23.11018

[21] F. Smulders, A. Kamp, and C. Fortin, "The CDIO framework and new perspectives on technological innovation," 2018. 


\section{Authors}

Nhi Thi Nguyen received the Ph.D. degree in Scientific education, from the Vinh University, Vietnam. She has acquired enormous working experiences as a Lecturer and a Researcher in teacher traning. She is currently a Senior Lecturer with the Vinh University, Vietnam. She has published several research papers in prestigious international journals and conference proceedings. Her research interests span a broad range of interesting topics, including physics education, education management, higher education, STEM education, teacher training, teaching methods and exploiting information technology in education and science.

Dr. Thanh Van Thai, a full professor in education science, has extensive experiences in academic activities and management. He was a lecturer, Vice Dean of Education Department, and Vice President for academic affairs at Vinh University during the 1990-2019 period. He is currently the Director of Nghe An Department of Education and Training and an invited professor at Vinh University. In addition to teaching, he has successfully supervised numerous M.A. students and a number of Ph.D. candidates. His research and publications center on application of information technology in teaching and management; innovation of teaching methods, assessment, curriculum development and quality assurance; school governance and development of teachers and educational leaders.

Huong Thi Pham received a Ph.D. in educational sciences in 2016 at Hanoi National University of Education, Vietnam. She has experience in professional training for high school teachers and university lecturers. She also participated in the development of pedagogical training programs, compiling professional training materials for high school teachers. She is currently the Head of Division of Biology Teaching Methodology at Vinh University with a great passion for teaching methods, educational sciences, experimental teaching, and STEM education.

Giang Chau Thi Nguyen received her PhD at Vinh University, Viet Nam and is currently a senior lecturer and educational researcher at this instituition. She has taken part in various professional development activities for teachers and published several articles on qualified international journals and conferences. Her research field includes mathematical education, educational management, higher education, teacher training and mentoring, theories of learning and teaching methods.

Article submitted 2020-05-11. Resubmitted 2020-06-13. Final acceptance 2020-06-15. Final version published as submitted by the authors. 